\title{
Cell Bank Characterization
}

National Cancer Institute

\section{Source}

National Cancer Institute. Cell Bank Characterization. NCI Thesaurus. Code C112950.

A process that takes a single pool of cells prepared from a selected cell clone and determines the characteristics of a sample of the cells including, but not limited to, checking for microbial or viral contaminants, the optimal growth conditions, and levels of expression of biologics. 